\title{
The Relativity of Liveability Rankings Examining the Japanese Case against the Global Discourse
}

\author{
Marco Capitanio ${ }^{1, *}$ \\ ${ }^{1}$ Faculty of Science and Technology, Keio University, Japan \\ *Correspondence: Faculty of Science and Technology, Keio University, 3-14-1 Hiyoshi, Kohoku-ku, Yokohama, \\ Kanagawa 223-8522, Japan. Tel: 81-45-566-1675. E-mail: capitanio@keio.jp
}

Received: August 28, 2017 Accepted: September 10, 2017 Online Published: October 15, 2017

doi:10.5430/wjss.v5n1p12 URL: https://doi.org/10.5430/wjss.v5n1p12

\begin{abstract}
Despite numerous lists ranking cities' or nations' liveability, and publications boasting comprehensive and sensible assessment methods, the assumption that liveability can be exhaustively defined, measured and compared is highly dubious. Despite a lack of academic consensus on a theoretical definition of liveability, at an operational level a number of liveability rankings are being used worldwide as benchmarking tools, often employed to promote the attractiveness of cities. In this research, we attempt to show the inconsistencies and biases behind the use of liveability rankings by examining how and by whom they are compiled. Three global and five Japanese liveability rankings will be analyzed, highlighting how assessment methods and liveability factors reflect the value system of the compiling institutions. By examining global and local liveability assessments, we show that the objective appraisal of quality of life is unfeasible, and that local characteristics, value systems etc. have to be taken into account when compiling and interpreting liveability rankings. They are, therefore, to be understood as relative and arbitrary benchmarking tools, in a global race of competitive urbanism.
\end{abstract}

Keywords: liveability rankings, liveability in Japan, liveable cities

\section{Introduction}

\subsection{The Problem of Defining Liveability}

Liveability is the result of a multitude of factors and circumstances, pertaining, among other things, to the built and natural environment, the socio-political and economic context, adjusting over time. Despite numerous lists ranking cities' or nations' liveability according to preselected factors (e.g. The Economist's Global Liveability Ranking, Mercer's Quality of Living Rankings, Monocle's Quality of Life Survey etc.) and publications boasting comprehensive and sensible assessment methods (Tan et al., 2012), the assumption that liveability can be exhaustively defined, measured and compared is highly dubious. While liveability measurements attempt to be holistic, there is no consensus on the specific factors taken into account, nor on their relevance or methodological assessment (The National Association of Regional Councils, 2012; Veenhoven, 2006). Moreover, as rankings tend to be shaped by a normative standpoint, following abstract and rigid classifications, regional nuances and contextual specificities are erased. Given the cross-disciplinary nature of the concept, every attempt to ultimately and quantitatively define liveability is biased by the researcher's own professional discipline and personal preconceptions (Radović, 2016). From this point of view, an "inclusive assessment of liveability is not feasible. The best we can do is to make promising condition profiles." (Veenhoven, 2006:12) Despite a lack of academic consensus on a theoretical definition of liveability, at an operational level a number of liveability rankings are being used worldwide as benchmarking tools, often employed to promote the attractiveness of cities. In this research, we attempt to show the inconsistencies and biases behind the use of liveability rankings by examining how and by whom they are compiled. We will see that such rankings serve pragmatic purposes and reflect the value system of the institutions compiling them. Let us now review the theoretical debate about liveability, before examining three of the most widespread liveability rankings on a global scale, and then focus our attention on five liveability rankings in Japan, as a way to highlight their inconsistencies and biases. 


\subsection{The Origins of Liveability and its Relation to Sustainability}

Judging by the amount of coverage that the academic and non-academic world dedicate to liveability, we might think that the concept is a younger sibling of the equally popular term "sustainability". In reality, the origins of liveability, when considered from a broad point of view, could be traced back to Aristotle, IV century BC. With eudaimonia he described a state of prosperity and welfare in city-states of his time, and much of Aristotle's production was devoted to the pursue of a "good life". Between the III century BC and the II century AD good life, from the point of view of individuals, was the core preoccupation of the philosophical school known as Stoicism. For stoic philosophers good life was one lived with virtue and reason, i.e. according to the nature of rational human beings: an active and engaged life blessed with tranquility and free of negative emotions (Irvine, 2009:35-43). Among other historical traces of liveability, it shall suffice to point out the fresco titled The Allegory of Good and Bad Government in Siena's town hall, Italy, painted in the late 1330s by A. Lorenzetti. It is a depiction of liveability, or the lack of it, as a consequence of good or bad urban administration. As an additional example, the link between governance and high-quality city life was explored by Italian intellectual L. Muratori in a 1749 treaty about the public good, or, according to his definition, "public happiness".

Even though liveability has often been equaled to sustainability, there is a growing amount of literature that grants liveability a more autonomous role. Nonetheless, the two agendas tend to overlap. Some point out that liveability is more concerned with the present state of a city or neighborhood and is not so much focused on future outcomes, while others highlight the fact that measures of liveability are locational, i.e. stress the idea of place, while sustainability takes into account a broader range of variables (Ling \& Yuan, 2009:156-7). In comparison with sustainability, "liveability focuses less on abstract themes and on more specific human needs and people's subjective reactions to places." (Wheeler, 2007:503). Compared to sustainability, its area of intervention is restricted to the neighborhood and city scale, focussing less on environmental metrics and more on human activities. Some authors suggest that liveability results from the combination of urban environmental quality and human wellbeing (Kallidaikurichi \& Yuan, 2010:192), so that "key elements of a liveable city often include attractive public spaces, walkable, mixed use, higher density neighbourhoods that support a range of green infrastructure and transport, affordable housing, [...] human-scaled pedestrian experiences." (Ling \& Yuan, 2009:3) Others prefer to focus on more quantifiable aspects, pairing liveability with low-carbon developments and lifestyles (Pickerill, 2013), while Wagner \& Caves (2012) highlight the importance of community and social infrastructure.

Sustainability and liveability go often hand in hand and they mutually support each other though. In this respect, the city of Melbourne states that "[1]iveability reflects the wellbeing of a community and represents the many characteristics that make a location a place where people want to live now and in the future." (VCEC, 2008:xxi) The city council has stated five main principles to be pursued, namely retaining local character, ensuring connectivity, higher density living, diversity in land use and ensuring a high quality public realm (Ling \& Yuan, 2009:157-8). Much confusion over liveability is caused by the different unit of analysis, or different scale, considered in rankings. In fact, while lists of most liveable cities tackle the city scale, other rankings asses either national (e.g. OECD Better Life Index, UNDP Human Development Index) or neighborhood liveability (e.g. AARP Liveability Index). For the purpose of this research, we will only consider rankings at the city or district scale.

\subsection{The Hypothesis of a Relative Definition}

We have now established that liveability is very much determined by the specific goals, aspirations, habits etc. of each community, and it is thus impossible to pin down in absolute (latin etymology: ab-solutum, i.e. unconditional) terms, being a relative concept. It has also become clear that liveability is: locational, changing with the spatial and temporal context (e.g. Ruth \& Franklin, 2014); open-ended, being the result of multifarious actors (e.g. Batty \& Marshall, 2009:567-570; Lynch, 1984:38-59); negotiatory, mediating between individual and civic interests (e.g. Tomba, 2014, Sennett, 2003). These statements, though, tell us what liveability is about, not what liveability is. Therefore, in this research, we propose to simply define liveability as the alignment between desired and actual living environment aiming at the betterment of the community as a whole. Let us now explore how this relative definition explains the difference among global and local liveability rankings.

\section{Method}

Three global liveability rankings will be first analyzed, highlighting the nature of the institution which produces them and the assessment factors used to compile such rankings. Afterwards, five liveability rankings in Japan will be similarly examined. Assessment methodologies and results will then be compared, in an attempt to show how every 
"most liveable city" reflects the value system and the interests of the respective compiling institutions.

\section{Results}

We will now introduce three of the most popular liveability rankings worldwide: the Economist's Intelligence Unit Liveability Ranking, Mercer's Quality of Life Rankings and Monocle's Quality of Life Survey.

\subsection{Liveability Rankings Worldwide}

I) The Economist's Intelligence Unit Global Liveability Ranking (The Economist, 2017) is compiled by the homonymous business magazine and classifies its chosen factors into five categories: stability (weight 25\%), healthcare (weight 20\%), culture and environment (weight 25\%), education (weight 10\%) and infrastructure (weight 20\%). Usually, cities in Canada, Australia and Central Europe top the list. Most notably, the cost of living is not considered, and the results tend to be anglocentric, i.e. favoring cities where English is widely spoken, at least as a second language.

II) Mercer's Quality of Life Rankings (Mercer, 2017) is compiled by the homonymous human resources consulting firm and aims at supporting other firms in the relocation of their employees. The ranking is thus directly helpful in determining how much a transferred employee should be compensated, according to the chosen location. The assessed factors are: safety, education, hygiene, health care, culture, environment, recreation, political-economic stability, public transport and access to goods and services. As in the Economist's ranking, cities in Central Europe, Australia and Canada top the list. A peculiar characteristic of Mercer's methodology is that all cities receive a score benchmarked against New York's score, which is set to 100.

III) The monthly lifestyle magazine Monocle compiles an annual Quality of Life Survey (Monocle, 2017) that has been coupled since 2015 with a Quality of Life Conference. The stated aim of this ranking is to consider more qualitative, cultural and aesthetic factors for the assessment of cities' liveability. Since 2015, after implementing a new methodology, Tokyo has been at the top of Monocle's list, a rather unexpected result, given its absence in other major rankings. The assessed factors are: safety/crime, cost of living, international connectivity, climate/sunshine, quality of architecture, public transport, tolerance, environmental issues/access to nature, urban design, business conditions, pro-active policy developments, medical care. As Monocle targets cosmopolitan, (single) urban readers, enjoying frequent travels and abundant free time, its ranking deliberately grants much importance to factors relating to personal wellbeing and entertainment.

\subsection{Liveability and its Rankings in Japan}

Similarly to the international context, in Japan the concept of liveability is used in multifarious situations. Its popularity has contributed to dilute and stretch its meaning. Etymologically, a literal translation of "liveability" is 居 住性 (kyojūsei), but, in popular culture and for explanatory reasons, a number of related words and expressions are to be found, such as:

- 賑わい (nigiwai): prosperity/bustle

・住みよさ (sumiyosa): liveability

- 住みたい街 (sumitai machi): a town where one wants to live

- 生き生きした町 (ikiiki shita machi): lively/vivid town

- 住み心地の良い町 (sumigokochi no yoi machi): comfortable town

Five examples of how differently liveability is assessed in Japan are as follows:

I) 積水ハウス椋試合祉: 都市を住み継ぐ本 - Sekisui House: The Book of Reading City Life (積水ハウス椋試 合祉, 2015)

The homebuilder Sekisui House compiled this booklet to orient its potential customers on issues relating to renting or building a house. The overarching theme is the idea that a lively, diverse urban neighborhood, with access to services, convenient transportation and enough green spaces is a good residential location, where flexible houses designed by the company could fit the needs of many types of customers. Of interest to us is a diagram (ivi:3) equating a neighborhood's attractiveness with its land value, rendering an explicitly investment-oriented and economic view of liveability. The message conveyed is that high land-values go hand in hand with quality of life. A further point of interest is the emphasis put on a triple meaning of the pronunciation "chien" as basis for good living and good aging: 地縁 (territorial bond), 血縁 (blood relationship) and 知縁 (connection with friends and 
acquaintances). Sekisui House's standpoint, in respect to liveability, is clearly addressing family life in a society where the impacts of aging are becoming more and more prominent.

II) 2015 年版 みんなが選んだ住みたい街ランキング 関東版 - 2015 Kanto Ranking: Choosing Where to Live (Recruit Sumai Company, 2015)

The real estate company SUUMO conducted an inquiry, asking 3000 people living in Tokyo, Saitama, Chiba, Kanagawa and Ibaraki prefectures, where they would like to live. All respondents had bought a house within the previous five years in one of the above-mentioned prefectures, and had to indicate the name of a train station representing the neighborhood where they would ideally live. The most popular station was Kichijoji, but SUUMO explicitly mentioned the good performance of Musashi Kosugi, occupying the 5th position. Other stations in the top 5 ranks were Ebisu, Yokohama and Meguro. The most popular city or ward resulted Setagaya Ward, followed by Minato, Meguro and Bunkyo wards, and Musashino City occupying the 5th position. These cities and wards are relatively central, vibrant and well-connected areas, with a good offer of services and facilities. SUUMO' ranking seems to reflect the view of company workers with a family, who have to consider commuting time when choosing where to live, given their long working hours. From this point of view, this ranking suggests that liveability is a balance between high accessibility, comfort and offer of services and amenities.

III) 2012 東京都内生活者実感ランキング - 2012 People’s daily life experience ranking, Tokyo (NEXT, 2012)

NEXT, the company behind the real estate portal HOME'S, conducted an inquiry asking a sample of 150 residents in each ward and city of Tokyo about their satisfaction in regard to the following criteria: daily shopping fulfillment, access to facilities, convenience of transportation, parenting and education, nature and environment, municipal public service, local community, safety, area's future prospects. As in the previous ranking, Musashino City resulted the most popular city, followed by Fuchu City, Suginami, Chuo and Shinagawa wards. This ranking seems more appropriate to evaluate the status quo of Tokyo's wards and cities, rather than to define most liveable places, since respondents were merely asked to express their satisfaction with their own area.

IV) 東洋経済の住みよさランキング 2016 - Toyo Keizai’s Liveability Ranking 2016 (東洋経済, 2016)

Toyo Keizai is an established weekly business magazine, compiling since 1993 an annual liveability ranking of Japanese cities. In 2016 their most liveable city was, as in the previous 5 years, Inzai, a municipality in Chiba Prefecture. Since the mid-1980s, Inzai has been part of a new town project, and is a suburban area of detached houses, some 60 minutes by train to central Tokyo. This ranking clusters 15 assessed factors into 5 categories, namely safety, convenience, comfort, wealth and housing situation. The complete list of assessed factors is as follows: safety (hospital/general clinic bed number per capita - facilities for elderly care - number of births - child care facilities per capita), convenience (retailers' annual commodity sales amount - large retail stores per capita), comfort (sewage treatment diffusion - park area per capita - population turnover and transfer ratio - construction of new housing per household), wealth (fiscal power index - amount of local tax revenue - amount of taxable income), residential situation (floor area per household - homeownership ratio). Unsurprisingly, the point of view of a business magazine results in an economy-based outcome, as the liveability of a town is equated with the affluence of its inhabitants and on exclusively quantitative and abstract data. In fact, all top three areas are nondescript places, such as the above mentioned Inzai, Nagakute in Aichi Prefecture and Tonami in Toyama Prefecture. In this respect, regular columnists for The Japan Times P. Brasor and M. Tsubuku (catforehead, 2012), residents of Inzai, have expressed their puzzlement upon reading the outcome of Toyo Keizai's ranking.

V) Sensuous City - 官能都市 (HOME’S 総研所長, 2015)

The real estate agency HOME'S produced in 2015 an extensive report bearing the English title "Sensuous City", based on a questionnaire survey. The stated aim was to produce a ranking which might be able to capture bodily qualities and attractivity of places, in contrast to quantitative surveys, such as the one produced by Toyo Keizai. 134 Japanese cities or districts within large cities were surveyed: Bunkyo Ward (Tokyo) topped the list, followed by Kita Ward (Osaka), Musashino City (Tokyo), Meguro Ward (Tokyo) and Nishi Ward (Osaka). The report introduces eight factors: belonging to the community, possibility for anonymity, feeling of romance, meeting chances, food culture, urban character, feeling of nature, walkability. As the publication clearly outlines, HOME'S intention was to rely on subjective feelings to evaluate how liveable a certain area is. From this point of view, a bottom-up approach similar to the one used by NEXT was followed, directly asking local residents about their views. This seems to be a more appropriate way to evaluate the liveability of a place, rather than comparing qualitative factors from external observation. 


\section{Discussion}

Table 1 classifies the assessed factors found in the three global rankings. It can be seen that liveability is a multidisciplinary concept, whose definition pertains to two main fields of study: morphology of the physical space, and urban management. As the boundary between these realms is not clear-cut, there is much overlapping, so that a comprehensive definition of liveability from the point of view of a single discipline is unfeasible. As Knox \& Mayer (2009:24) put it, "liveability is a complex, multifaceted concept." We can now better understand the reasons behind the criticism of rankings and benchmarking of cities. First, while quantitative comparisons have a methodological justification, qualitative ones are much harder to perform. How can we compare qualitative and thus subjective aspects, solely based on our point of view? Second, the analyzed factors merely represent outcomes, while the processes that have constituted them remain hidden. From this point of view, judging the development of cities over time might harvest more insightful results. Third, as we have seen, the choice of assessed factors seems arbitrary and is hardly explained. How is one to select relevant criteria that have to be kept constant for all cities? How would local inhabitants pick such criteria? Fourth: rankings are an attempt to impose a theoretical, global model upon concrete and local situations; they are a one-way deductive process. Instead of aspiring to an idealized goal, the focus should rather be on the unique characteristics of each city, as "liveability is essentially local in character" (ibid.).

Table 1. Assessed Liveability Factors in Three Global Rankings

\begin{tabular}{lll}
\hline The Economist & Mercer's & Monocle's \\
Global Liveability Ranking & Quality of Living Rankings & Quality of Life Survey \\
\hline Stability & Safety & Safety/crime \\
Healthcare & Education & Cost of living \\
Culture \& environment & Hygiene & International connections \\
Infrastructure & Healthcare & Climate/sunshine \\
& Culture & Quality of architecture \\
& Envornment & Public transport \\
& Recreation & Tolerance \\
& Political-economic stability & Environment \& nature \\
& Public transport & Urban design \\
& Access to goods \& services & Business conditions \\
& & Pro-active policy \\
& & Medical care \\
\hline
\end{tabular}

The amount and selection of liveability factors, despite presenting similarities, can differ greatly.

As in the case of worldwide rankings, a discourse on liveability in Japan suffers from similar questionable standpoints, and, therefore, is subject to similar critiques. Nonetheless, an important difference is to be noted: as the assessed cities or neighborhoods lie in the same country or even in the same region, and their number is limited, enquiries and questionnaires have been sometimes used to directly ask local population about their own preferences. This is a crucial point, in that it opens a bottom-up perspective that seems able to question or prove ranking methodology. By hearing locals, other points of view could be considered and the scientific validity of results could be strengthened. Such methods are appropriate when there is homogenous access to a pool of respondents and when like-minded individuals (e.g. of a certain nationality or residing in a definite cultural region) are inquired. A study of this kind would be unfeasible on a worldwide scale, as the approach of respondents toward questionnaires and local circumstances dramatically vary, inhibiting comparison.

\section{Conclusions}

Contrary to the assumptions of liveability rankings, by examining global and local liveability assessments, we have demonstrated that the objective appraisal of quality of life is unfeasible, and that local characteristics, value systems 
etc. have to be taken into account when compiling and interpreting liveability rankings. As such, these rankings should be seen as mere tools to represent and compare quality of life according to the worldview of the compiling institutions, aiming at a specific audience. We maintain that liveability rankings can be deceiving tools since they are presented as objective and comprehensive assessments, despite the lack of a valid theoretical and methodological definition of liveability. They are to be understood as arbitrary benchmarking tools, in a global race of competitive urbanism.

This study was limited to three liveability rankings worldwide and five Japanese ones; more examples in different countries should be analyzed to further prove the hypothesis that a definition and assessment of liveability are relative and greatly depend on the specificities of local contexts. Nonetheless, we believe that this paper has bridged some of the gap between a theoretical understanding of liveability, and its operational assessment.

\section{Acknowledgements}

I would like to express my gratitude to Prof. Darko Radović: his comments were crucial in refining the structure and content of this paper. Funding for this research has been provided by GESL Program at Keio University, Tokyo.

\section{References}

Batty, M., \& Marshall, S. (2009). The evolution of cities: Geddes, Abercrombie and the new physicalism. Town Planning Review, 80(6), 552-574. https://doi.org/10.3828/tpr.2009.12

catforehead. (2012). We're the top. https://catforehead.com/2012/07/04/were-the-top/

HOME'S 総研所長. (2015). Sensuous City. Tokyo. http://www.homes.co.jp/souken/

Irvine, W.B. (2009). A guide to the good life: the ancient art of Stoic joy. New York: Oxford University Press.

Kallidaikurichi, S., \& Yuen, B. (Eds.) (2010). Developing Living Cities: From Analysis to Action. Singapore; Hackensack, N.J: World Scientific Publishing Company. https://doi.org/10.1142/7722

Knox, P.L., \& Mayer, H. (2009). Small Town Sustainability: Economic, Social, and Environmental Innovation. Basel; Boston: Birkhäuser Architecture. https://doi.org/10.1515/9783034608978

Ling, O.G., \& Yuan, B. (Eds.) (2009). World Cities: Achieving Liveability and Vibrancy. Singapore; Hackensack, N.J: World Scientific Publishing Company.

Lynch, K. (1984). Good City Form. Cambridge, Massachussets: The MIT Press.

Mercer (2017). Quality of living city rankings. Retrieved from https://mobilityexchange.mercer.com/Insights/quality-of-living-rankings

Monocle (2017). Where to live well. Retrieved from https://monocle.com/magazine/issues/105/where-to-live-well/.

NEXT (2012). 東京都内生活者実感ランキングべスト 20. Tokyo. http://www.next-group.jp/files/news/press-research/121204.pdf

Pickerill, J. (2013). Building liveable cities. Urban Low Impact Developments as low carbon solutions? In H. Bulkeley, V. Castán Broto, M. Hodson \& S. Marvin (Eds.), Cities and Low Carbon Transitions (pp. 178-197). London: Routledge.

Radović, D. (2016). Measuring the non-measurable: On mapping subjectivities in urban research. City, Culture and Society, 7(1), 17-24. https://doi.org/10.1016/j.ccs.2015.10.003

Recruit Sumai Company (2015)。「2015 年版 みんなが選んだ住みたい街ランキング関東版」を発表/リク ルート住まい力ンパニ 一. Tokyo: Recruit Sumai Company. http://www.recruit-sumai.co.jp/press/2015/03/2015-1.html

Ruth, M., \& Franklin, R.S. (2014). Livability for all? Conceptual limits and practical implications. Applied Geography, 49(The New Urban World), 18-23. https://doi.org/10.1016/j.apgeog.2013.09.018

Sennett, R. (2003). Respect in a World of Inequality. New York: W. W. Norton \& Company.

Tan, K.G., Woo, W.T., Tan, K.Y., Low, L., \& Aw, G.E.L. (2012). Ranking the Liveability of the World's Major Cities: The Global Liveable Cities Index. Singapore; Hackensack, N.J: World Scientific Publishing Company. https://doi.org/10.1142/8553 
The Economist (2017). The global liveability ranking. Retrieved from https://www.eiu.com/topic/liveability

The National Association of Regional Councils (2012). Livability literature review: a synthesis of current practice. Washington. Retrieved from http://narc.org/wp-content/uploads/Livability-Report-FINAL.pdf

Tomba, L. (2014). The Government Next Door: Neighborhood Politics in Urban China. New York: Cornell University Press.

VCEC (2008). A State of Liveability: An Inquiry into Enhancing Victoria's Liveability. Melbourne: VCEC. http:/www.-vcec.-vic.-gov.-au/-CA256EAF001C7B21-/-pages/-vcec--inquiries--completed--inquiry--into--enha ncing--victoria's--liveability

Veenhoven, R. (2006). The four qualities of life. Ordering concepts and measures of the good life. In M. McGillivray, \& M. Clarke (Eds.) Understanding Human Well-being (pp. 74-100). Tokyo-New York-Paris: United Nations University Press.

Wagner, F., \& Caves, R. (Eds.) (2012). Community Livability: Issues and Approaches to Sustaining the Well-Being of People and Communities. New York: Routledge.

Wheeler, S.M. (2004). Planning for Sustainability: Creating Livable, Equitable and Ecological Communities. London; New York: Routledge. https://doi.org/10.4324/9780203300565

積水八ウス椋試合祉 (2015). 都市を住及継ぐ本. Tokyo.

東洋経済 (2016). 最新!「住みよさランキング 2016」トップ50|住みよさランキング|東洋経済オンライ ン| 経済ニュースの新基準. 東洋経済. http://toyokeizai.net/articles/-/122614 